Article

\title{
Individual and Combined Coatings of Chitosan and Carnauba Wax with Oregano Essential Oil to Avoid Water Loss and Microbial Decay of Fresh Cucumber
}

\author{
María Melissa Gutiérrez-Pacheco ${ }^{1}$, Luis Alberto Ortega-Ramírez ${ }^{1}$, \\ Brenda Adriana Silva-Espinoza ${ }^{1}$, Manuel Reynaldo Cruz-Valenzuela ${ }^{1}$ (D), \\ Gustavo Adolfo González-Aguilar ${ }^{1}{ }^{\circledR}$, Jaime Lizardi-Mendoza ${ }^{1}\left(0\right.$, , Raquel Miranda ${ }^{2}$ and \\ Jesús Fernando Ayala-Zavala $1, *$ (i)
}

1 Centro de Investigación en Alimentación y Desarrollo, A.C., Carretera Gustavo Enrique Astiazarán Rosas, No. 46, Col. La Victoria, Hermosillo, Sonora 83304, Mexico; melissa.gtzpacheco@gmail.com (M.M.G.-P.); ingeluis_100@hotmail.com (L.A.O.-R.); bsilva@ciad.mx (B.A.S.-E.); reynaldo@ciad.mx (M.R.C.-V.); gustavo@ciad.mx (G.A.G.-A.); jalim@ciad.mx (J.L.-M.)

2 Department of Biochemistry and Molecular Biology, Federal University of Ceara, Av. Mister Hull 2297, Fortaleza, Ceara 60440-554, Brazil; rmiranda@ufc.br

* Correspondence: jayala@ciad.mx

Received: 20 May 2020; Accepted: 26 June 2020; Published: 29 June 2020

\begin{abstract}
The objective of the present study is to evaluate the effect of individual and combined coatings of chitosan $\left(0.008 \mathrm{~g} \cdot \mathrm{mL}^{-1}\right)$ and carnauba wax $\left(0.1 \mathrm{~g} \cdot \mathrm{mL}^{-1}\right)$ with oregano essential oil $\left(\mathrm{OEO}, 0.08 \mathrm{~g} \cdot \mathrm{mL}^{-1}\right)$ to reduce dehydration and microbial decay of fresh cucumbers stored at $10{ }^{\circ} \mathrm{C}$. Chitosan-OEO-wax films showed the lowest water vapor transmission rate $\left(0.141 \mathrm{~g} \cdot \mathrm{m}^{-2} \cdot \mathrm{h}^{-1}\right)$, compared to single chitosan films $\left(0.257 \mathrm{~g} \cdot \mathrm{m}^{-2} \cdot \mathrm{h}^{-1}\right)$. While chitosan-OEO films completely inhibited the in vitro growth of Alternaria alternata and reduced the growth of Salmonella Typhimurium, Escherichia coli $\mathrm{O} 157: \mathrm{H7}$, mesophilic bacteria, and fungi isolated from decayed cucumbers. Besides, the infrared analysis of chitosan-OEO-wax films showed shifts in $\mathrm{O}-\mathrm{H}$ and $\mathrm{N}-\mathrm{H}$ absorption bands, indicating possible hydrogen bonding between the components. Wax and wax-OEO were the most effective coatings to prevent weight loss in cucumbers during 15 days of storage at $10^{\circ} \mathrm{C}$, while the most effective antimicrobial treatments were chitosan and chitosan-OEO. Therefore, these results showed that carnauba wax and carnauba wax-OEO coatings were the most effective in weight loss, whereas chitosan and chitosan-OEO were the most effective to reduce the microbial load of the treated fresh cucumber.
\end{abstract}

Keywords: Cucumis sativus L.; dehydration; antimicrobial activity; bilayer coating; essential oils

\section{Introduction}

Cucumber (Cucumis sativus L.) is a low-calorie fruit belonging to the Cucurbitaceae family, non-climacteric, harvested, and consumed at an immature stage. It is a rich source of potassium, magnesium, iron, with a high water content-approximately $90 \%$ [1]. The quality of cucumber is based on its shape uniformity, dark green color, firmness, size, absence of defects, and rot [2]. However, during post-harvest, the cucumber is highly susceptible to physiological changes, microbial decay, and dehydration with the consequent loss of appearance, and nutritional quality [3]. Also, it is susceptible to the attack of bacteria (e.g., Erwinia spp. and Xanthomonas spp.) and fungi (e.g., Alternaria spp. and Rhizopus spp.) [4]. Commonly, some of these problems are solved with the use of low storage temperatures; however, cucumbers are sensitive to chilling injury below $10^{\circ} \mathrm{C}$; for this reason, they are stored at $10-12.5^{\circ} \mathrm{C}$, becoming more susceptible to quality loss after 14 days. These problems 
justify the need for developing adequate water loss barrier and antimicrobial techniques to preserve the cucumbers' quality.

Edible coatings can act as barriers to reduce water loss and gas exchange, depending on their composition [5]. Different materials are used to formulate edible coatings, including proteins, lipids, and polysaccharides. Polysaccharides have excellent gas barrier properties; however, they are highly hydrophilic and show high water vapor permeability. On the other hand, lipids are hydrophobic compounds with water barrier properties, although, their nonpolymeric nature limits their ability to form films with good mechanical integrity [5]. Among polysaccharides, chitosan obtained from alkaline deacetylation of chitin has been widely used because of its antimicrobial properties [6]. Chiabrando et al. [7], reported that chitosan coatings significantly reduced microbial decay of minimally processed nectarines compared to control fruits. Similarly, chitosan coatings $(2 \%)$ in broccoli florets stored at $5{ }^{\circ} \mathrm{C}$ resulted in a significant reduction of total mesophilic and psychrotrophic bacteria; also, a bactericidal effect was observed in the inoculated E. coli O157:H7 [8]. In addition, Pavinatto et al. [9] reported a reduction of gray fungus attack and an insignificant alteration in flavor, appearance, aroma, and texture of strawberries coated with $1 \%$ chitosan and stored for 7 days at $25^{\circ} \mathrm{C}$. Other polysaccharide-based coatings also have been applied to improve the quality parameters of fruits. Aloe vera coatings ( $3 \%)$ improved firmness and total soluble solids of tomato; however, no effect was observed in weight loss compared to control [10]. Similarly, alginate coatings showed a good gas permeability and maintained the firmness of fresh-cut melon; however, no antimicrobial activity and weight loss protection were observed. Besides their different benefits, polysaccharides-based coatings are considered a low water barrier [11].

On the contrary, natural waxes (carnauba, shellac, and beeswax) limit the water loss better than polysaccharides-based coatings. Carnauba wax is a lipid-based material obtained from Copernicia cerifera leaves, predominantly comprised of aliphatic esters and diesters of cinnamic acid with a high melting point and low solubility [12]. These characteristics grant the relatively inert and stable character to carnauba wax; in addition, it is generally recognized as safe by the Food and Drug Administration of the United States and normally used in edible coatings formulations [5,12]. Won and Min [13] reported a significant reduction in the weight loss of Satsuma mandarins treated with carnauba wax $(18.1 \%)$ during storage at 4 and $25^{\circ} \mathrm{C}$ for 28 days compared with control fruits. In addition, the weight loss was significantly reduced in Valencia oranges and avocados after the application of carnauba wax $[14,15]$. However, it is important to note that these authors did not evaluate the antimicrobial effect of these coatings, microbial decay being one of the main factors that compromise the postharvest life of these fruits, highlighting the need for an additional coating material as our study proposes. Therefore, it can be expected that a combination of constituents could obtain better results.

Edible coatings may carry antimicrobial additives protecting fresh produce of postharvest decay [16]. Oregano essential oil (OEO) possess antimicrobial activity, and it may be added to edible coatings as a food additive; its efficacy has been proved when added into several edible coatings [17,18]. The antibacterial activity of OEO is attributed to the constituents carvacrol and thymol; as a result of their lipophilic nature, these monoterpenes can become embedded in the bacteria or fungi membrane causing the alteration of enzymatic systems, cellular disruption, and loss of cellular constituents $[19,20]$. Some studies reported the efficacy of the combination of chitosan and carnauba wax with essential oils to maintain the postharvest quality of cucumber and other fruits. Mohammadi et al. [21] reported that nanochitosan-based coating loaded with Zataria multiflora essential oil improved physicochemical quality and significantly reduced total bacterial, yeasts, and molds counts of cucumber stored at $10{ }^{\circ} \mathrm{C}$ for 21 days. Won and Min [13] also reported that the addition of OEO provides an antimicrobial activity to carnauba wax coatings. However, these studies did not characterize the physicochemical properties of the coatings, which is important to compare the responses with those observed in vivo. Therefore, the present study evaluated the effect of individual and combined coatings of chitosan and carnauba wax with $\mathrm{OEO}$ to reduce dehydration and microbial decay of fresh cucumbers. 


\section{Materials and Methods}

\subsection{Chemicals}

Medium molecular weight chitosan (75\%-85\% deacetylation), carnauba wax yellow No.1, glycerol, and anhydrous calcium chloride were obtained from Sigma-Aldrich (St. Louis, MO, USA). Glacial acetic acid was obtained from JT Baker (Madrid, Spain), while the coconut oil was obtained from Oils by Nature Inc. (Solon, OH, USA).

\subsection{Plant Materials}

Cucumber (Cucumis sativus L.) fruits were harvested in a field in Hermosillo, Sonora, Mexico (29 $\left.17^{\circ} 20.4^{\prime \prime} \mathrm{N} 110^{\circ} 54^{\prime} 35.0^{\prime \prime} \mathrm{W}\right)$ after 57 days from flowering, at a slightly immature state, with a dark green color visually determined by using the color comparator for medium green CC-1 proposed by the USDA, uniform in shape, size, weight and free from growth defects and decay; in addition, firmness, $\mathrm{CO}_{2}$ production and color of cucumbers were determined (Table 1). OEO (Lippia graveolens L.) was obtained from ORE Procesadora de Oregano Silvestre [22], Chihuahua, Mexico.

Table 1. Firmness, $\mathrm{CO}_{2}$ production, and color of cucumbers.

\begin{tabular}{cc}
\hline Parameter & Mean \pm Standard Deviation \\
\hline Firmness $(\mathrm{N})$ & $48.80 \pm 1.89$ \\
$\mathrm{CO}_{2}$ production rate $(\mathrm{mL} \mathrm{CO} / \mathrm{kg} \cdot \mathrm{h})$ & $1.10 \pm 0.65$ \\
Color & - \\
Lightness & $29.21 \pm 1.01$ \\
Chroma & $59.50 \pm 13.19$ \\
Hue & $132.76 \pm 0.54$ \\
\hline
\end{tabular}

\subsection{Film Formulation}

For chitosan films, $0.8 \mathrm{~g}$ of chitosan and $0.2 \mathrm{~g}$ of glycerol were dispersed in $100 \mathrm{~mL}$ of $1 \%$ glacial acetic acid solution and stirred at $25^{\circ} \mathrm{C}$ for $24 \mathrm{~h}$. The filmogenic mixture was filtered using cheesecloth to remove small impurities, sterilized at $121^{\circ} \mathrm{C}$ for $15 \mathrm{~min}$, and cooled at $25^{\circ} \mathrm{C}$. Subsequently, $20 \mathrm{~mL}$ of the chitosan dispersion was cast on Petri dishes with diameters of $8 \mathrm{~cm}$ and dried at $25^{\circ} \mathrm{C}$ for $24 \mathrm{~h}$. Then the films were peeled off from the plates and stored in a desiccator for further analysis. For carnauba wax films, a 10\% carnauba wax solution was made by melting $10 \mathrm{~g}$ of wax in $90 \mathrm{~mL}$ of coconut oil heated at $70{ }^{\circ} \mathrm{C}$ with constant stirring. Bilayer films (chitosan-carnauba wax and chitosan-OEO-carnauba wax) were elaborated by brushing $0.5 \mathrm{~mL}$ of the carnauba wax on the preformed chitosan films. For the films added with $\mathrm{OEO}, 0.2 \mathrm{~g}$ of Tween 20 and $8 \mathrm{mg} \cdot \mathrm{mL}^{-1}$ of $\mathrm{OEO}$ (this concentration was selected based on the minimal inhibitory concentration of OEO against microbiota of decayed cucumbers) were added directly into the chitosan and carnauba wax for their individual coatings, and in the chitosan-wax coating the oil was added into the carnauba wax. Each formulation was mixed at 13,500 rpm for 5 min in a Kinematica Polytron homogenizer PT 1200C (Cambridge Scientific Products, Watertown, MA, USA).

\subsection{Characterization of the Formulated Films}

\subsubsection{Thickness and Water Vapor Transmission (WVT)}

Film thickness was measured with a digital micrometer (E.J. Cady and Co., Wheeling, IL, USA); three measurements were carried out at different points of 5 films per treatment (chitosan, chitosan-wax, chitosan-OEO, and chitosan-OEO-wax) and results were expressed in millimeters (mm). WVT was determined gravimetrically based on the American Society for Testing and Materials method (ASTM) [23]; for this, each film was placed in the top of a moisture permeation cell (118.64 $\mathrm{cm}^{3}$ volume) with $30 \mathrm{~g}$ of dried calcium chloride beads to ensure a relative humidity $(\mathrm{RH})$ of $0 \%$ inside the cell. Subsequently, the cells were placed in a desiccator (volume $1500 \mathrm{~cm}^{3}$ ) containing $70 \mathrm{~mL}$ of a saturated 
solution of magnesium nitrate to ensure $90 \% \mathrm{RH}$ and left at $25^{\circ} \mathrm{C}$ for $8 \mathrm{~h}$. The water mass transferred through the film and adsorbed by the calcium chloride was determined by the weight gained for each permeation cell. Cells were weighed each hour for eight hours, and the slope of weight gain vs. time was obtained by linear regression. The following formula determined the WVT of the films: $\mathrm{WVT}=m / a$, where $m$ is the slope of weight gain vs. time, and $a$ is the film area where the mass transfer occurred. The analysis was performed by triplicate, and results were expressed as grams of water per square meter per hour $\left(\mathrm{g} \mathrm{m}^{-2} \cdot \mathrm{h}^{-1}\right)$. Because of the experimental complexity, the thickness and WVTR of the individual wax films were not evaluated.

\subsubsection{In Vitro Antimicrobial Capacity of the Formulated Films}

Cucumber microbiota (mesophilic bacteria and fungi) isolated from decayed fruits, Salmonella enterica subspecies enterica serovar Typhimurium (ATCC ${ }^{\circledR}$ 14028), Escherichia coli O157:H7 (ATCC ${ }^{\circledR}$ 43890), and Alternaria alternata (ATCC ${ }^{\circledR}$ 6663) were exposed to the formulated films. The antimicrobial assay was carried out based on the dilution method described by the National Committee for Clinical Laboratory Standards [24], with some modifications. For the antimicrobial assay, $20 \mathrm{mg}$ of each film $\left(2 \mathrm{mg} \cdot \mathrm{mL}^{-1}\right)$ was introduced into tubes containing $10 \mathrm{~mL}$ of Mueller Hinton or potato dextrose broth for bacteria and fungi, respectively. After $15 \mathrm{~min}$, tubes were inoculated with $1 \times 10^{6}$ colony-forming units per milliliter (CFU mL ${ }^{-1}$ ) of each challenged bacteria or fungi. Subsequently, $1.0 \mathrm{~mL}$ from each tube was plated in Mueller Hinton or acidified potato dextrose agar and incubated at $37 \pm 2{ }^{\circ} \mathrm{C}$ for $24 \mathrm{~h}$ and $25 \pm 2{ }^{\circ} \mathrm{C}$ for five days for bacteria and fungi, respectively. The analysis was performed by triplicate, the microbial colonies were counted, and the results were expressed as $\log C F U \mathrm{~mL}^{-1}$ and compared with a control without films.

\subsubsection{Fourier Transform Infrared Spectroscopy (FTIR)}

FTIR spectra (Instrument Corp. Madison, WI, USA) were obtained to evaluate physicochemical interactions among the film components (chitosan, wax, chitosan-wax, chitosan-OEO, and chitosan-OEO-wax). Data were recorded in the transmission mode using a spectrophotometer FTIR Nicolet Protegé 460 (Instrument Corp. Madison, WI, USA) under a wavenumber range of $4000-400 \mathrm{~cm}^{-1}$ with a resolution of $4\left(\mathrm{~cm}^{-1}\right)$, taking 64 scans at a rate of $0.63\left(\mathrm{~s}^{-1}\right)$. Solid samples were pressed within $\mathrm{KBr}$ pellets, and liquid samples (OEO and carnauba wax) were placed over preformed pellets, respectively.

\subsection{Effect of the Formulated Coatings on Water Loss and Microbial Decay of Fresh Cucumbers}

\subsubsection{Coating Application}

A total of 252 cucumbers (whole and unpeeled) were used in this experiment; 216 fruits were divided into six groups and coated with each treatment, and 36 fruits were left uncoated as controls. Cucumbers were washed with chlorinated water (200 ppm) for $3 \mathrm{~min}$ and air-dried at $25^{\circ} \mathrm{C}$, and coated manually with brushes (1.5-inch-wide, Maxtool ${ }^{\circledR}$, Mexico City, Mexico), adding uniformly $0.5 \mathrm{~mL}$ of each treatment per cucumber. For applying bilayer coatings, cucumbers were first coated with chitosan and dried with forced air at $25{ }^{\circ} \mathrm{C}$ for $10 \mathrm{~min}$; afterward, wax (with and without OEO) was applied, then cucumbers were stored on polypropylene trays at $10{ }^{\circ} \mathrm{C}$ and $90 \% \mathrm{RH}$. The effects of edible coatings on the weight loss and microbial spoilage of the fruit were assessed in three trays with two cucumbers per treatment at $0,3,6,9,12$ and 15 days.

\subsubsection{Fruit Weight Loss}

The fruit was weighed at $0,3,6,9,12$ and 15 days of storage at $10{ }^{\circ} \mathrm{C}$, and the slope of weight loss vs. time was obtained by linear regression. Weight loss was measured using the equation: $(A-$ $B) / A$, where $A$ was the initial weight $(\mathrm{g})$ at $t_{0}$, while $B$ was the weight $(\mathrm{g})$ at a given storage time $\left(t_{\mathrm{n}}\right)$. The analysis was performed by triplicate, and results were expressed as weight loss (\%). 


\subsubsection{Changes of Microbial Load of the Coated Fruit}

Total mesophilic bacteria, molds and yeasts were counted on $0,3,6,9,12$ and 15 days of storage at $10{ }^{\circ} \mathrm{C}$. Cucumbers were sampled $(10 \mathrm{~g})$ and homogenized for $1 \mathrm{~min}$ in $90 \mathrm{~mL}$ of peptone water. Subsequently, decimal dilutions were made, and $1 \mathrm{~mL}$ of each sample was poured on plate count agar or potato dextrose acidified agar, and incubated at $37 \pm 2{ }^{\circ} \mathrm{C}$ for $24 \mathrm{~h}$ or $25 \pm 2{ }^{\circ} \mathrm{C}$ for five days, for mesophilic bacteria and for molds and yeasts, respectively [25]. The analysis was performed with four replicates, and results were expressed as Log CFU.g ${ }^{-1}$.

\subsection{Statistical Analysis}

The effect of the films composition (chitosan, chitosan-wax, chitosan-OEO, wax-OEO, and chitosan-OEO-wax) on the WVT, thickness, and in vitro antimicrobial capacity was evaluated with a completely randomized design. The effect of the edible coatings over dehydration and microbial spoilage was a completely randomized experimental design with a factorial arrangement $(5 \times 6)$, where the factors were the coating treatments (chitosan, wax, chitosan-wax, chitosan-OEO, wax-OEO, and chitosan-OEO-wax) and the storage time $(0,3,6,9,12,15$ days), and the analyzed responses were weight loss and microbial growth. All experiments were done by triplicate, expressing the results as means \pm standard deviation. An analysis of variance (ANOVA) was performed, and means were compared by the Tukey Kramer test $(p \leq 0.05)$ using the statistical software NCSS 2007 (NCSS, LLC, Kaysville, UT, USA).

\section{Results}

\subsection{Characterization of the Formulated Films}

\subsubsection{FTIR Spectra}

Figure 1 shows the infrared spectra of OEO (a), chitosan (b), wax (c), chitosan-OEO (d), and wax-OEO (e) in the wavelength range of 4000-400 $\mathrm{cm}^{-1}$. OEO spectrum showed at 3361 and $2958 \mathrm{~cm}^{-1}$ the characteristic peaks of $\mathrm{O}-\mathrm{H}$ and $\mathrm{C}-\mathrm{H}$ stretching, respectively; these signals could be attributed to the presence of carvacrol and thymol. On the other hand, the peaks of the $\mathrm{C}=\mathrm{O}$ stretch (amide I) and flexion for the $\mathrm{N}-\mathrm{H}$ group (amide II) of the chitosan were identified at a wavenumber around 1645 and $1554 \mathrm{~cm}^{-1}$, respectively (Figure $1 \mathrm{~b}$ ). These peaks represent the $\mathrm{N}$-acetylglucosamine structure, which could be found in chitosan with a low acetylation degree [26]. Also, at $3334 \mathrm{~cm}^{-1}$, the corresponding absorption band of the $\mathrm{O}-\mathrm{H}$ stretching was observed. On the other hand, a shift in the $\mathrm{O}-\mathrm{H}$ stretching peak of the chitosan was observed $\left(\Delta_{\mathrm{OH}}=11\right)$ when combined with OEO (Figure 1c), which could be attributed to the interactions between the terpenoids and chitosan. Figure $1 \mathrm{~d}$ showed the spectrum of carnauba wax with the $\mathrm{C}-\mathrm{H}$ and $\mathrm{C}=\mathrm{O}$ stretching signals observed at 2930 and $1743 \mathrm{~cm}^{-1}$, respectively. In contrast, no changes were observed in the wax spectrum after the addition of $\mathrm{OEO}$, which indicated the lack of interaction between these components (Figure 1e). 


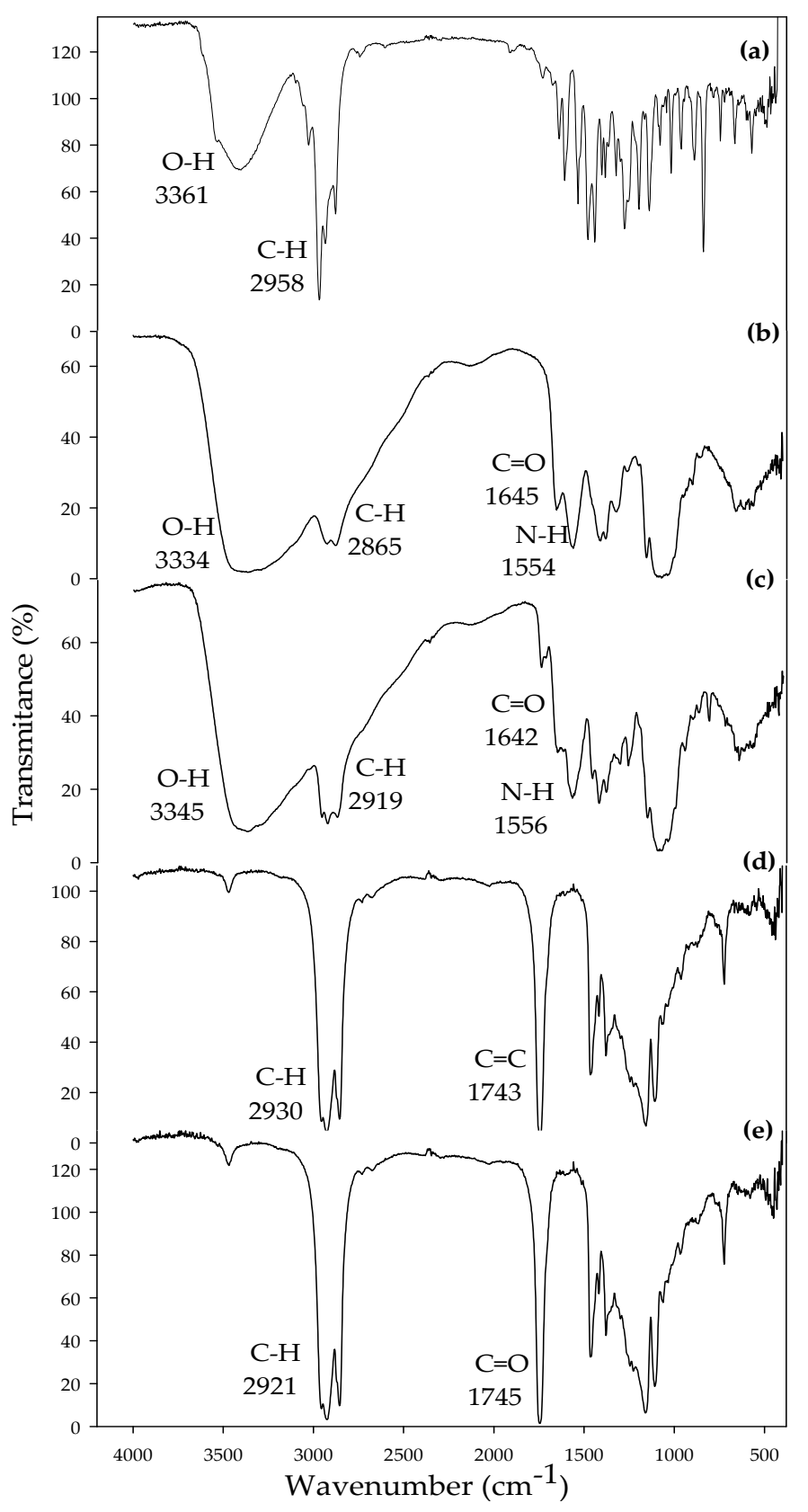

Figure 1. Fourier transform infrared spectroscopy (FTIR) spectra of oregano essential oil (OEO) (a), chitosan (b), chitosan-OEO (c), wax (d), and wax-OEO (e) films.

Moreover, the addition of wax on the chitosan film (chitosan-wax film) caused a shift toward higher frequencies in the absorption bands of the $\mathrm{O}-\mathrm{H}\left(\Delta_{\mathrm{OH}}=50\right)$ and $\mathrm{C}=\mathrm{O}$ stretch of amide $\mathrm{I}\left(\Delta_{\mathrm{CO}}=48.2\right)$, and the presence of the characteristic $\mathrm{C}=\mathrm{O}$ peak of the fatty acid esters (Figure 2a). The same behavior was observed in the chitosan-OEO-wax film (Figure 2b), where the maxima absorption of the O-H (stretching), $\mathrm{C}=\mathrm{O}$ (stretching), and $\mathrm{N}-\mathrm{H}$ (flexion) peaks were shifted toward higher frequencies $\left(\Delta_{\mathrm{OH}}=7.7, \Delta_{\mathrm{CO}}=44.85\right.$, and $\left.\Delta_{\mathrm{NH}}=14\right)$. This behavior reflected that the incorporation of wax or OEO on the chitosan films could affect the maxima absorption peaks of the groups responsible for the antibacterial activity. Similar results were reported by Kaya et al. [27], who observed a shift of the N-H and $\mathrm{O}-\mathrm{H}$ absorption peaks of chitosan after the addition of Berberis crataegina fruit extract, indicating hydrogen bond formation between the $\mathrm{NH}_{2}$ group of the chitosan molecule and the $\mathrm{O}-\mathrm{H}$ group of the fruit phenolic compounds. It is well-known that changes in the absorption spectra (in frequency and 
shape) can be correlated with physicochemical interactions among the components [27]. In this sense, special attention must be given to $\mathrm{O}-\mathrm{H}$ and $\mathrm{N}-\mathrm{H}$ groups, considering that their electronic changes could cause variations in the properties of the film [28]. Based on this, an additional NMR analysis could be made to confirm the interactions between these components. Also, it is well-known that the antimicrobial activity of the OEO is related to the active hydroxyl groups of carvacrol and thymol [29]; therefore, any interaction in these sites could lead to a reduction of this property.

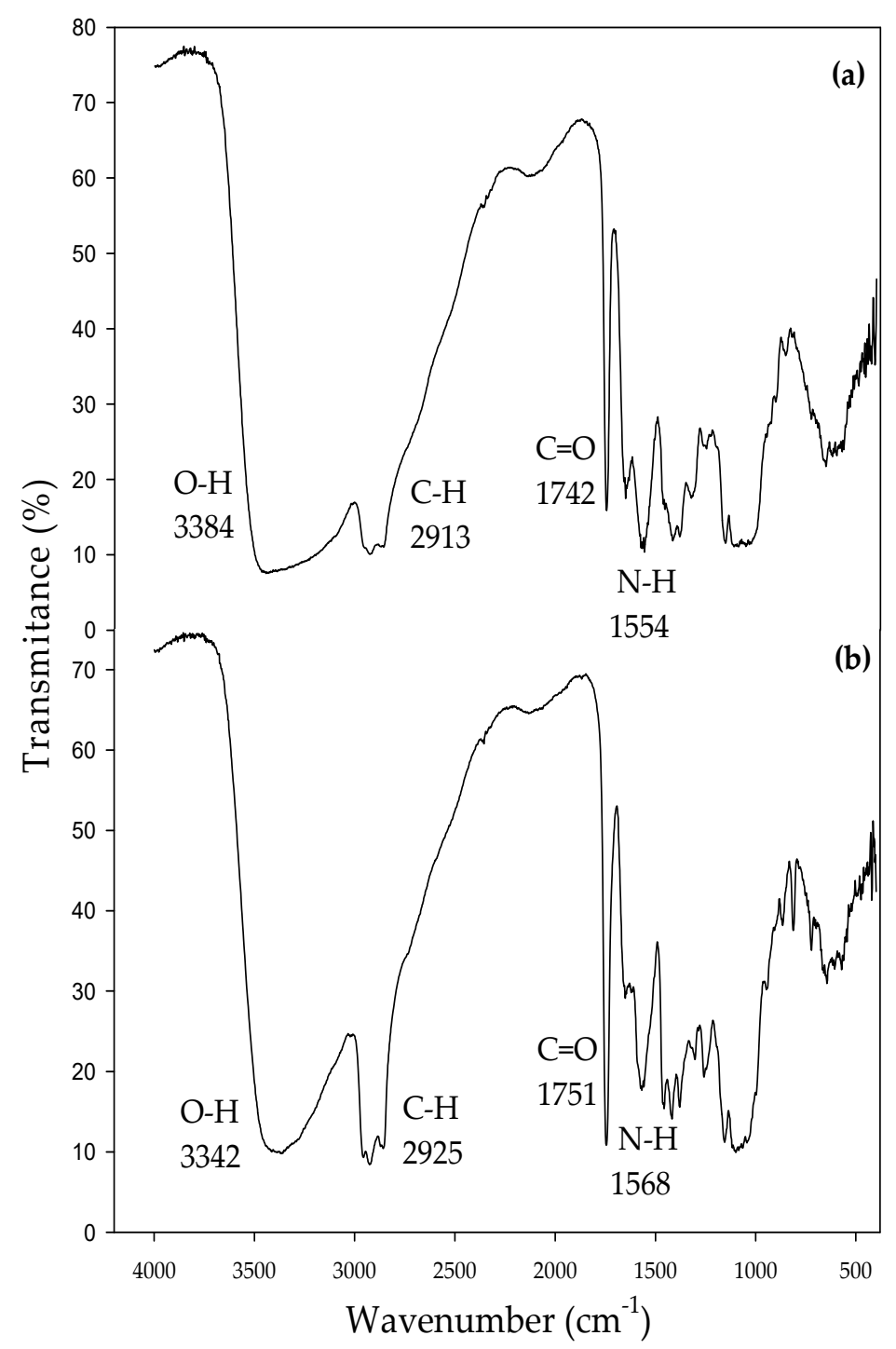

Figure 2. FTIR spectra of chitosan-wax (a) and chitosan-OEO-wax (b) films.

Several studies have tested the effect of the formulation on the film properties [30,31]; however, few studies have analyzed the physicochemical interactions among the constituents as the present study did. Considering that the presence and availability of certain functional groups grant the specific properties to the formulated materials, it becomes crucial to study their interactions and impact on the films functionality.

\subsubsection{Thickness and WVT}

Table 2 shows the results of thickness and WVT of the formulated films; the thickness was similar $(p \geq 0.05)$ for chitosan, chitosan-wax, and chitosan-OEO, being the thickness of the chitosan-OEO-wax film the highest $(p \leq 0.05)$ of all treatments. Chitosan films showed the highest WVT, followed by chitosan-OEO, with no significant differences between them $(p<0.05)$. Moreover, chitosan-wax and 
chitosan-OEO-wax films reduced the WVT by $35 \%$ and $45 \%$, respectively, compared to chitosan films. The WVT and FTIR spectra results could support the discussed interaction of chitosan O-H groups with the wax functional groups (Figure 2a,b). In this sense, the decrease in WVT after the wax incorporation could be attributed to the limited availability of free $\mathrm{O}-\mathrm{H}$ groups, which could cause a decrease in the absorption of water molecules and thus lower its permeability.

Table 2. Thickness and WVT of edible films constituted by chitosan, OEO, and carnauba wax at $25^{\circ} \mathrm{C}$.

\begin{tabular}{|c|c|c|}
\hline Film & Thickness $(\mathrm{mm})$ * & WVT $\left(g / \mathrm{m}^{2} \mathrm{~h}\right) * *$ \\
\hline Chitosan & $0.025 \pm 0.007^{a * * *}$ & $0.257 \pm 0.013^{a}$ \\
\hline Chitosan-OEO & $0.022 \pm 0.002^{\mathrm{a}}$ & $0.241 \pm 0.019^{a}$ \\
\hline Chitosan-Wax & $0.027 \pm 0.005^{\mathrm{a}}$ & $0.167 \pm 0.012^{b}$ \\
\hline Chitosan-OEO-Wax & $0.037 \pm 0.004^{b}$ & $0.141 \pm 0.008^{b}$ \\
\hline
\end{tabular}

Several studies have shown a decrease in the water vapor permeability of polysaccharide films with the incorporation of lipidic compounds [30]. Ochoa, Almendárez, Reyes, Pastrana, López, Belloso and Regalado-González [30] developed composite films with low WVT and antimicrobial activity based on corn starch, beeswax, lauric alginate, and natamycin. However, they did not study the contribution of each component to the efficacy of the whole film, as the present study did. In the same study, an increment of thickness from 0.050 to $0.064 \mathrm{~mm}$ after beeswax incorporation was recorded. Similarly, Santos et al. [32] observed an improvement in the water barrier properties of chitosan films after the addition of beeswax. Haq et al. [33] reported a 50\% lower water vapor permeability of gum Cordia films added with beeswax. Agar/maltodextrin films showed better barrier properties when beeswax was added as a bilayer [34]. Therefore, hydrophilic-based films with a coat of hydrophobic material could diminish the WVT. This lower WVT could be a good alternative to decreased weight loss in fresh produce caused by dehydration; this approach is shown in Section 3.2.1.

\subsubsection{In Vitro Antimicrobial Activity of Films}

Figure 3 shows the antimicrobial activity of edible films against bacteria (a) and fungi (b) isolated from the decayed cucumber. Figure 3 a showed that after incubation at $37^{\circ} \mathrm{C}$ for $24 \mathrm{~h}$, chitosan-OEO films showed the greatest in vitro reduction $(p \leq 0.05)$ of bacteria isolated from cucumber $(3.23 \mathrm{Log}$ $\mathrm{CFU} \cdot \mathrm{mL}^{-1}$ ), while the wax-OEO films reduced by about $1 \mathrm{Log} C \mathrm{CFU} \cdot \mathrm{mL}^{-1}$. Also, chitosan and chitosan-wax films showed a reduction $(p \leq 0.05)$ of 0.4-0.6 Log CFU.mL ${ }^{-1}$; however, chitosan, wax, chitosan-wax, and chitosan-OEO-wax showed bacterial counts similar to the control with no differences among them $(p \geq 0.05)$. A similar pattern can be observed in Figure $3 b$, where chitosan-OEO showed the highest reduction (1.12 Log CFU. $\mathrm{mL}^{-1}$ ) of fungal counts compared to the control ( $\left.p \leq 0.05\right)$. In addition, chitosan, wax, chitosan-wax, and chitosan-OEO-wax showed no differences among them $(p \geq 0.05)$ against fungal counts; it has to be mentioned that these treatments showed fungal counts significantly lower than the control (0.47-0.63 Log CFU. $\mathrm{mL}^{-1}$ reduction). 


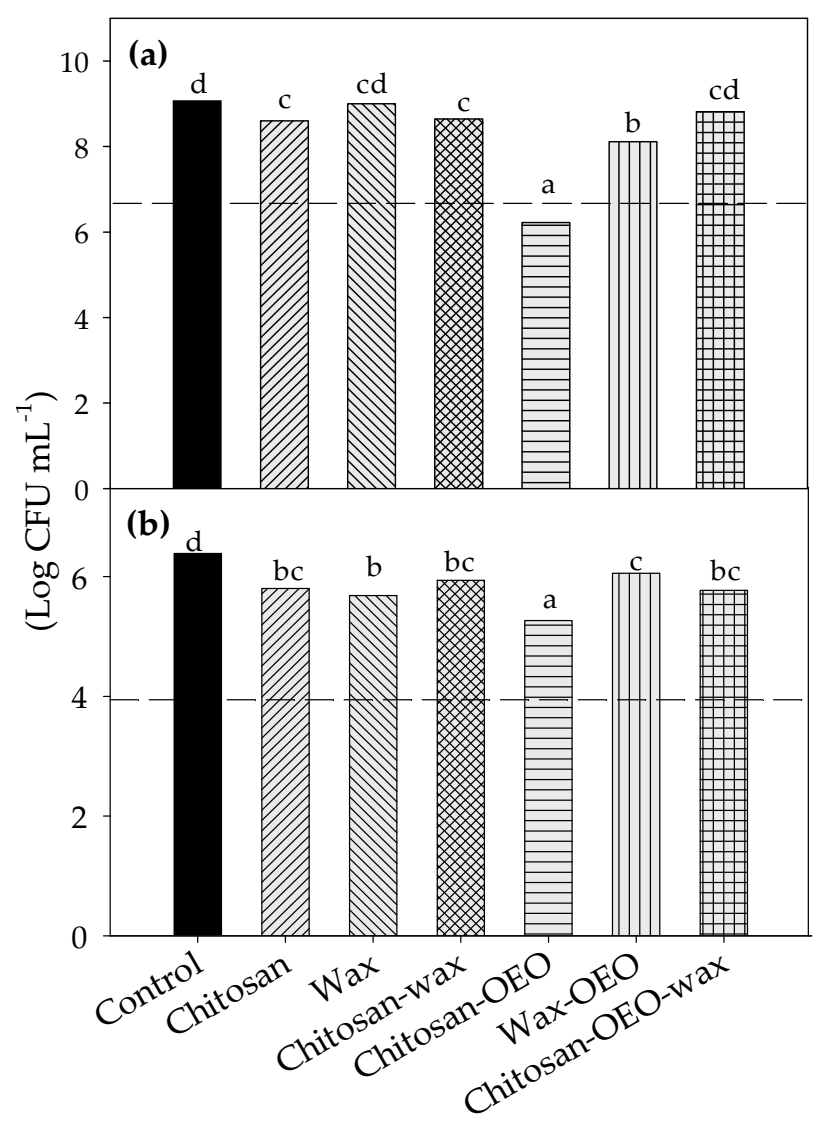

Figure 3. Antimicrobial activity of chitosan, carnauba wax, and oregano essential oil (OEO) films against mesophilic bacteria (a) and fungi (b) isolated from the decayed cucumber. Dotted lines signify the added inocula, and different letters among bars indicate significant differences $(p \leq 0.05)$.

Figure 4 shows the in vitro antibacterial effect of edible films against $S$. Typhimurium (a) and E. coli O157:H7 (b). It was observed that the addition of OEO into chitosan films improved $(p \leq 0.05)$ the antibacterial activity against $S$. Typhimurium (3.12 Log CFU. $\mathrm{mL}^{-1}$ reduction) compared to the control after $24 \mathrm{~h}$ of incubation at $37^{\circ} \mathrm{C}$ (Figure 4a). On the other hand, chitosan and wax-OEO films significantly reduced Salmonella counts by 1.25 and $0.79 \mathrm{Log} \mathrm{CFU} \cdot \mathrm{mL}^{-1}$, respectively. However, wax, chitosan-wax, and chitosan-OEO-wax films did not inhibit the growth of $S$. Typhimurium, showing counts similar $(p \geq 0.05)$ to the control. On the other hand, for E. coli O157:H7, chitosan-OEO films reduced 3.45 Log CFU. $\mathrm{mL}^{-1}$ (Figure $4 \mathrm{~b}$ ), while chitosan and chitosan-wax reduced 1.58 and $0.43 \mathrm{Log}$ $\mathrm{CFU} \cdot \mathrm{mL}^{-1}$, respectively. Wax, wax-OEO, and chitosan-OEO-wax films showed no effect against E. coli O157:H7.

Figure 5 shows the fungicidal effect of the chitosan-OEO film against $A$. alternata. On the other hand, it was observed that chitosan-OEO-wax reduced $3 \mathrm{Log} \mathrm{CFU} \cdot \mathrm{mL}^{-1}$, compared to the untreated fungus after five days at $25^{\circ} \mathrm{C}$. On the other hand, no differences were observed among chitosan, wax-OEO, and control, showing similar fungal counts. Furthermore, wax films did not inhibit the growth, showing counts $2.3-5 \mathrm{Log} C \mathrm{CH} \cdot \mathrm{mL}^{-1}$ higher $(p \leq 0.05)$ than other treatments and control. The antimicrobial potential of chitosan-OEO films could be attributed to the action of each component. The antimicrobial activity of chitosan could be exerted by the interaction of its amino groups with the phospholipids in the bacterial membrane, leading to loss of functionality [28]. On the other hand, different studies suggest that carvacrol and thymol, major OEO components, may disintegrate the outer membranes of microorganisms because of their physicochemical interactions with lipids and proteins, causing a release of the cellular content and affecting viability [20]. It is important to mention that the reduced activity of wax-OEO and chitosan-OEO-wax films (versus the effect observed in chitosan-OEO films) could be attributed to a low diffusion of OEO compounds due to the different 
components of coating's structure or their affinity to the hydrophobic phase of wax, reducing the oils migration from the film. In this sense, more studies are needed to characterize the diffusion of OEO compounds throughout these coating systems.

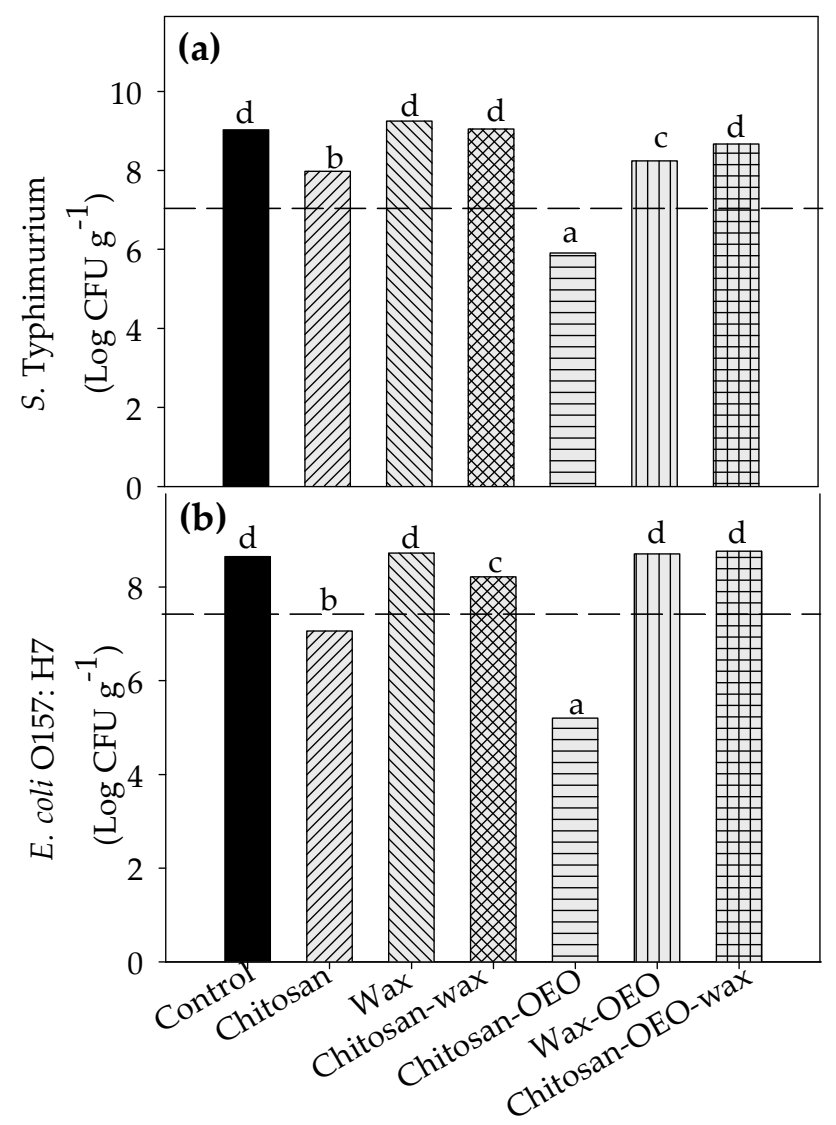

Figure 4. Antibacterial activity of chitosan, oregano essential oil (OEO), and carnauba wax films against S. Typhimurium (a) and E. coli O157:H7 (b) Dotted lines indicate the initial bacterial load, and different letters among bars indicate significant differences $(p \leq 0.05)$.

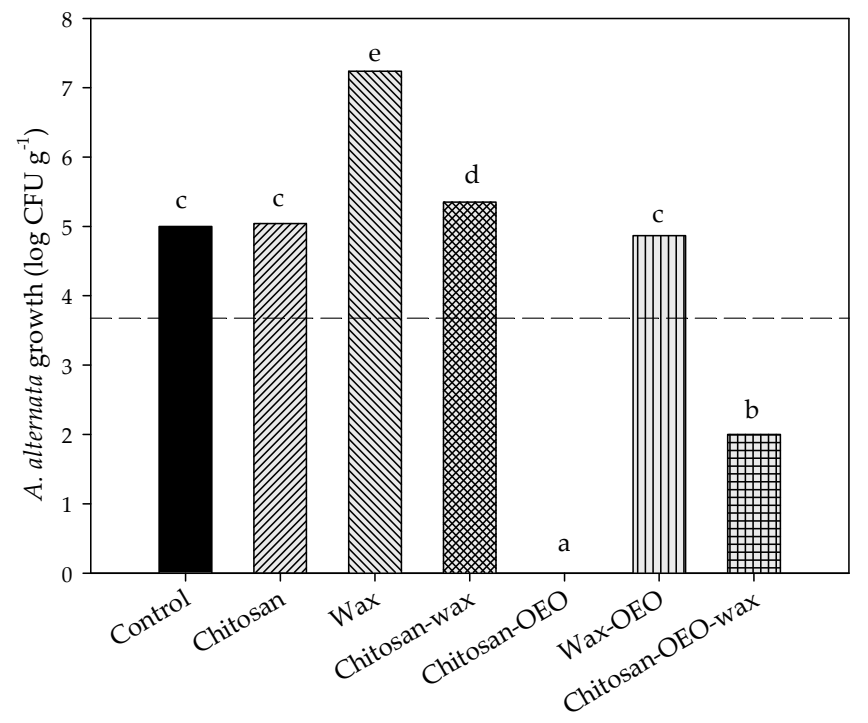

Figure 5. Antifungal activity of chitosan, oregano essential oil (OEO), and carnauba wax films against A. alternata. The dotted line indicates the initial fungal load, and the different letters indicate significant differences $(p \leq 0.05)$. 
Several studies have shown the ability of chitosan in carrying plant compounds to inhibit the growth of pathogenic bacteria [35]. Fernández-Pan et al. [36] reported that chitosan films with 20\% carvacrol (the main terpene of OEO) reduced the growth of Pseudomonas fragi, Shewanella putrefasciens, and Aeromonas hydrophila. Similarly, Yuan et al. [37] observed an increase in the antibacterial activity of chitosan films against Staphylococcus aureus and E. coli after the addition of $10 \mathrm{mg} \cdot \mathrm{mL}^{-1}$ of carvacrol. On the other hand, chitosan films incorporated with Thymus piperella essential oil reduced the growth of Serratia marcescens and Listeria innocua [38]. Chitosan alone or combined with OEO has also shown fungicidal activity against Botrytis cinerea, Penicillium sp., Rhizopus stolonifer, and A. alternata. As mentioned above, the polycationic structure of this compound is responsible for its antifungal properties. Chitosan could induce morphological and structural changes in fungal cells by causing molecular disorganization [28]. Finally, the incorporation of OEO within chitosan films improved their antimicrobial activity, which was reflected by the significant reduction of bacterial and fungal growth.

\subsection{Postharvest Changes of Coated Cucumbers}

\subsubsection{Coating Influence on Postharvest Weight Loss}

Table 3. shows the weight loss of coated cucumbers stored at $10{ }^{\circ} \mathrm{C}$ for 15 days. Wax and wax-OEO treatments significantly reduced cucumber weight loss by $0.18 \%-1.63 \%$ compared to control fruits, with wax coatings the most effective $(p \leq 0.05)$ compared to the other treatments, which showed similar losses to those of control fruits. On the other hand, chitosan coatings caused no decrement of cucumber weight loss, which was expected given their hydrophilic characteristics. Based on the WVT results described in Section 3.1.2, it was expected that there would be a better barrier property when carnauba wax was added to chitosan film; however, no differences $(p \geq 0.05)$ were observed between chitosan, chitosan-OEO, chitosan-wax, wax-OEO, and chitosan-OEO-wax. WVT was measured at $25^{\circ} \mathrm{C}$, while cucumbers were stored at $10^{\circ} \mathrm{C}$. This condition was corroborated by microphotographs from fruit coated with wax and stored at 25 and $10{ }^{\circ} \mathrm{C}$. The carnauba wax coated cucumber stored at $25^{\circ} \mathrm{C}$ showed a smooth and homogenous surface (Figure 6a), but the fruit with the same treatment and stored at $10{ }^{\circ} \mathrm{C}$ showed a rough surface (Figure 6b), with the appearance of crystals (Figure 6c). Meanwhile, the chitosan and chitosan-OEO coated cucumbers showed a homogeneous coated surface at both temperatures (data not shown). Some factors influencing these phenomena could be the interaction between coating components and the temperature and cooling rate. Natural waxes in coating formulations tend to crystallize at low temperatures, and at low crystallization rates, bigger crystals can be formed, acquiring an amorphous and porous structure. All these structural changes could alter the wax stability, becoming more fragile and permeable to water. For this reason, it is possible that the low efficiency of this coating could be attributed to this phenomenon [39-41].

Table 3. Weight loss of cucumbers coated with chitosan, $\mathrm{OEO}$, and carnauba wax and stored at $10{ }^{\circ} \mathrm{C}$ for 15 days.

\begin{tabular}{cc}
\hline Treatment & Weight Loss at Day 15 (\%) \\
\hline Control & $7.11 \pm 0.20^{\mathrm{b} *}$ \\
Chitosan & $7.18 \pm 0.50^{\mathrm{b}}$ \\
Wax & $5.48 \pm 0.50^{\mathrm{a}}$ \\
Chitosan-wax & $7.42 \pm 0.21^{\mathrm{b}}$ \\
Chitosan-OEO & $7.66 \pm 0.29^{\mathrm{b}}$ \\
Wax-OEO & $6.93 \pm 0.10^{\mathrm{a}}$ \\
Chitosan-OEO-wax & $8.03 \pm 2.01^{\mathrm{b}}$ \\
\hline
\end{tabular}

Means \pm standard deviation, $n=9$. ${ }^{*}$ Different letters in the same column indicate significant differences $(p \leq 0.05)$. 


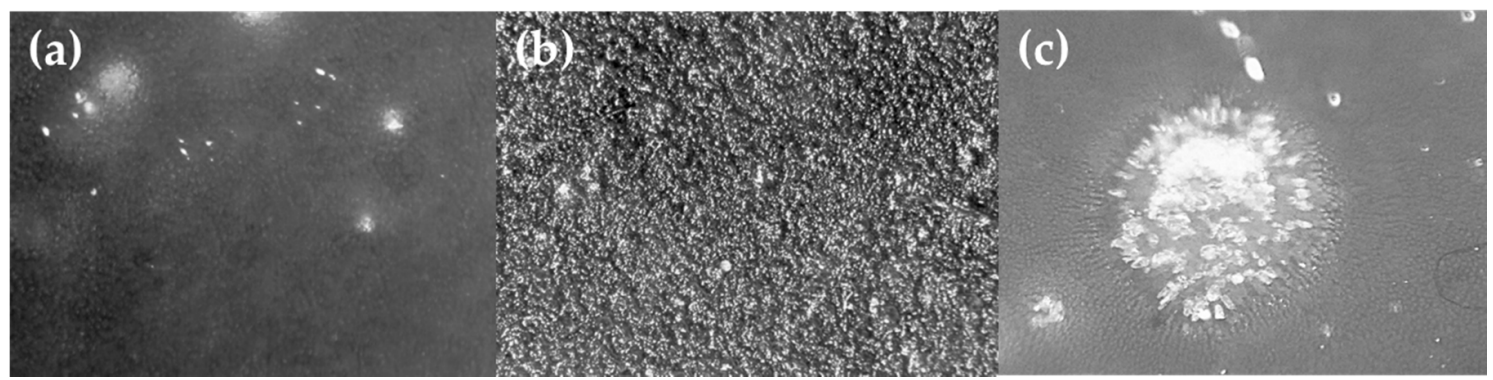

Figure 6. Stereoscopic microphotographs of the wax coated cucumbers stored at (a) $25^{\circ} \mathrm{C}$ and $(\mathbf{b}, \mathbf{c}) 10^{\circ} \mathrm{C}$; these images were acquired at a magnitude of $10 \times$.

Won and Min [13] reported that carnauba wax coating significantly reduced weight loss (18.1\%) of Satsuma mandarins treated with carnauba wax during storage at 4 and $25^{\circ} \mathrm{C}$ for 28 days, compared with control fruit. Also, weight loss was significantly reduced in Valencia oranges after the application of carnauba wax for eight weeks at 4 and $20^{\circ} \mathrm{C}$ [14]. Moreover, Miranda et al. [42] observed a similar trend when applying carnauba wax $(18 \%)$ to papaya fruit, obtaining a $70.6 \%$ reduction of weight loss compared to uncoated fruits after 6 days of storage at $20^{\circ} \mathrm{C}$. Therefore, the use of these coatings during storage at higher temperatures can be suggested to avoid crystallization and maintain the response observed in the WVT analysis at $25^{\circ} \mathrm{C}$.

\subsubsection{The Microbial Load of Coated Cucumbers}

Table 4 shows the bacterial counts of cucumbers stored at $10{ }^{\circ} \mathrm{C}$ for 15 days. A decrease of bacterial counts due to the coating application was observed on day 0 , and there was a slight increase on day 3 , showing all treatments a bacterial growth lower than control. At day 6, wax, wax-OEO, and the bilayer coatings showed an increment of $0.1-1.62 \mathrm{Log} C \mathrm{CU} \cdot \mathrm{g}^{-1}$ of bacterial load. Moreover, chitosan and chitosan-OEO coatings maintained the cucumber bacterial loads significantly lower than control. However, at day 9 and 12 of storage, bacterial counts of chitosan-OEO increased. During the storage period, the chitosan coating maintained the lowest bacterial growth.

Table 4. Antibacterial activity of chitosan, OEO, and carnauba wax coatings on the mesophilic bacteria load of cucumbers stored at $10{ }^{\circ} \mathrm{C}$ for 15 days.

\begin{tabular}{cccccccc}
\hline \multirow{2}{*}{$\begin{array}{c}\text { Storage } \\
\text { (Days) }\end{array}$} & Control & Chitosan & Wax & $\begin{array}{c}\text { Chitosan-Carnauba } \\
\text { Wax }\end{array}$ & Chitosan-OEO Wax-OEO & $\begin{array}{c}\text { Chitosan- } \\
\text { OEO-Wax }\end{array}$ \\
\cline { 2 - 7 } & $6.70^{\mathrm{a} *}$ & $3.81^{\mathrm{b}}$ & $4.44^{\mathrm{b}}$ & $4.62^{\mathrm{b}}$ & $3.76^{\mathrm{b}}$ & $4.94^{\mathrm{b}}$ & $4.80^{\mathrm{b}}$ \\
0 & $6.0^{\mathrm{c}}$ & $4.80^{\mathrm{a}}$ & $5.45^{\mathrm{b}}$ & $4.90^{\mathrm{ab}}$ & $5.20^{\mathrm{ab}}$ & $5.36^{\mathrm{ab}}$ & $4.96^{\mathrm{ab}}$ \\
3 & $5.90^{\mathrm{b}}$ & $4.80^{\mathrm{a}}$ & $6.97^{\mathrm{c}}$ & $5.0^{\mathrm{a}}$ & $4.85^{\mathrm{a}}$ & $6.98^{\mathrm{c}}$ & $5.09^{\mathrm{a}}$ \\
9 & $5.23^{\mathrm{bc}}$ & $4.70^{\mathrm{a}}$ & $5.54^{\mathrm{c}}$ & $4.85^{\mathrm{ab}}$ & $5.51^{\mathrm{c}}$ & $5.34^{\mathrm{c}}$ & $5.11^{\mathrm{abc}}$ \\
12 & $6.19^{\mathrm{c}}$ & $5.22^{\mathrm{a}}$ & $5.39^{\mathrm{ab}}$ & $5.99^{\mathrm{c}}$ & $5.73^{\mathrm{bc}}$ & $6.30^{\mathrm{c}}$ & $5.80^{\mathrm{bc}}$ \\
15 & $7.37^{\mathrm{d}}$ & $5.78^{\mathrm{a}}$ & $6.90^{\mathrm{c}}$ & $6.68^{\mathrm{bc}}$ & $6.39^{\mathrm{b}}$ & $6.89^{\mathrm{c}}$ & $6.56^{\mathrm{b}}$ \\
\hline
\end{tabular}

The initial cellular load of mesophilic bacteria in cucumbers before coating was $6.7 \mathrm{Logs} \mathrm{CFU} \cdot \mathrm{g}^{-1}$. ${ }^{*}$ Different letters amongst rows indicate significant differences amongst treatments per day $(p \leq 0.05), n=4$.

As explained before, the antibacterial effect of chitosan is attributed to their amino groups; however, it is known that in multicomponent systems some interactions may occur among the functional groups of the components and the coated surface, causing a blockage of active sites and, hence, a reduction of antibacterial activity [28]. It is important to mention that chitosan only affects microorganisms that are in direct contact with its active sites [35]. Based on this, it can be supposed that carnauba wax led to a steric hindrance between the active sites of chitosan and bacteria. On the other hand, OEO components are volatile, and their presence could decrease during storage. Similar to this study, Moreira, Roura and Ponce [8] reported a significant bactericidal effect of chitosan coatings 
(with reductions of 1.5-2.5 Log CFU. ${ }^{-1}$ ) on aerobic mesophilic bacteria of treated broccoli, compared to uncoated samples. Chiabrando and Giacalone [43] reported that chitosan films caused higher reductions of yeasts $\left(<2.71 \mathrm{Log} \mathrm{CFU} \cdot \mathrm{g}^{-1}\right)$ and molds $\left(<1.05 \mathrm{Log} \mathrm{CFU} \cdot \mathrm{g}^{-1}\right)$ in fresh-cut nectarines stored at $4{ }^{\circ} \mathrm{C}$, compared to chitosan added with alginate. Similar to our study, Tokatlı and Demirdöven [44] demonstrated that chitosan caused a reduction of $2.71 \mathrm{Log} \mathrm{CFU} \cdot \mathrm{g}^{-1}$ in aerobic mesophilic bacteria of sweet cherries. Also, Alvarez et al. [45] reported that chitosan coatings (10 and $20 \mathrm{mg} \cdot \mathrm{mL}^{-1}$ ) reduced aerobic mesophilic counts $\left(2.5-3 \mathrm{Log} \mathrm{CFU} \cdot \mathrm{g}^{-1}\right)$ of broccoli florets stored at $7^{\circ} \mathrm{C}$, compared to uncoated florets.

Table 5 shows the mold and yeast counts of coated cucumbers stored at $10{ }^{\circ} \mathrm{C}$ for 15 days. It was observed that all treatments showed similar initial counts $(p \geq 0.05)$, being different from the higher values of uncoated fruit. However, chitosan-OEO-coated cucumbers showed the lowest counts (the half of the uncoated cucumbers counts). At day 6, no counts of molds and yeasts were detected on chitosan-OEO and chitosan-wax coated cucumbers, while uncoated fruits continue to increase to the end of the storage time. At the end of storage, the most effective treatment against molds and yeasts was chitosan-wax films, followed by chitosan-OEO, wax-OEO, wax, and chitosan-OEO-wax $(p \leq 0.05)$.

Table 5. Molds and yeast counts of fresh cucumber coated with chitosan, OEO, and carnauba wax and stored 15 days at $10^{\circ} \mathrm{C}$.

\begin{tabular}{|c|c|c|c|c|c|c|c|}
\hline \multirow{2}{*}{$\begin{array}{l}\text { Storage } \\
\text { (Days) }\end{array}$} & \multicolumn{7}{|c|}{$\log$ CFU.g ${ }^{-1 *}$} \\
\hline & Control & Chitosan & Wax & Chitosan-Wax & Chitosan-OEO & Wax-OEO & Chitosan-OEO-Wax \\
\hline 0 & $3.58^{\mathrm{c} *}$ & $2.14^{\mathrm{ab}}$ & $2.30^{\mathrm{ab}}$ & $2.18^{a b}$ & $1.82^{a b}$ & $2.72 \mathrm{bc}$ & $1.87^{\mathrm{a}}$ \\
\hline 3 & $5.07^{\mathrm{c}}$ & $3.72^{\mathrm{a}}$ & $5.22^{\mathrm{d}}$ & $4.12^{\mathrm{ab}}$ & $4.10^{\mathrm{ab}}$ & $4.69 \mathrm{bcd}$ & $4.27^{\mathrm{abc}}$ \\
\hline 6 & $4.30^{\mathrm{b}}$ & $3.0^{\mathrm{a}}$ & $3.53^{\mathrm{a}}$ & - & - & $3.37^{\mathrm{a}}$ & $3^{a}$ \\
\hline 9 & $4.25^{\mathrm{b}}$ & $3.20^{\mathrm{a}}$ & - & - & $4.13^{\mathrm{b}}$ & $3.07^{\mathrm{a}}$ & - \\
\hline 12 & $4.98^{\mathrm{c}}$ & $4.12^{b}$ & $3^{a}$ & $3.0^{\mathrm{a}}$ & $3^{a}$ & $4.05^{b}$ & - \\
\hline 15 & $5.02^{\mathrm{c}}$ & $3.94^{\mathrm{b}}$ & $3.55^{\mathrm{ab}}$ & - & $3^{a}$ & $3.30^{a b}$ & $3.69^{a b}$ \\
\hline
\end{tabular}

The observed effect of wax coating could be attributed to the oxygen barrier limiting the growth of aerobic microorganisms. Except for specific rumen-inhabiting species, fungi are strict aerobes or can grow only as microaerophiles [46]. Velickova et al. [47] reported that chitosan-beeswax coatings reduced the fungal infection of strawberries stored at $20{ }^{\circ} \mathrm{C}$ for 7 days. On the other hand, chitosan coatings (1\%) reduced the disease incidence of $B$. cinerea in grape berries by $16.9 \%$ and $28.4 \%$ after 12 and 24 days post-infection at $10{ }^{\circ} \mathrm{C}$, respectively [48]. In addition, it has been reported that a reduction of fungi infections in plants treated with chitosan, and this effect was attributed to the antifungal properties of chitosan and its ability to stimulate defense mechanisms, such as chitinase and phytoalexins [49]. It is important to mention that no major changes on the firmness of the coated cucumbers were observed during the experiment (Figure S1). Whereas the coated cucumbers showed higher ${ }^{\circ}$ hue values than the uncoated fruit (Figure S2), no significant changes on $L^{*}$ were observed among the treatments on control. Finally, the chitosan-wax and wax-OEO showed lower Chroma values than the uncoated fruit and the rest of the treatments.

\section{Conclusions}

The addition of carnauba wax helped to decrease the WVT of the formulated chitosan films and coatings. Furthermore, the addition of OEO to chitosan films increased the in vitro antimicrobial activity. Also, it can be concluded that the occurrence of physicochemical interactions among the components altered their individual properties. Finally, carnauba wax and carnauba wax-OEO coatings were the most effective in reducing weight loss, while chitosan and chitosan-wax were the most effective to reduce the microbial load of the treated fresh cucumber. 
Supplementary Materials: The following are available online at http://www.mdpi.com/2079-6412/10/7/614/s1, Figure S1: Global effect of chitosan, wax, chitosan-wax, chitosan-OEO, wax-OEO, and chitosan-OEO-wax coatings on the firmness of the cucumbers stored at $10{ }^{\circ} \mathrm{C}$ for 15 days. Values are means of $n=3$. Different literals among treatments indicate significant differences $(p \leq 0.05)$, Figure S2: Global effect of chitosan, wax, chitosan-wax, chitosan-OEO, wax-OEO, and chitosan-OEO-wax coatings on the surface color of the cucumbers stored at $10^{\circ} \mathrm{C}$ for 15 days. Values are means of $n=3$. Different literals among treatments in the same parameter indicate significant differences $(p \leq 0.05)$.

Author Contributions: Conceptualization, M.M.G.-P., L.A.O.-R., B.A.S.-E., M.R.C.-V., G.A.G.-A., J.L.-M., R.M., and J.F.A.-Z.; data curation, M.M.G.-P. and L.A.O.-R.; funding acquisition, J.F.A.-Z.; methodology, M.M.G.-P., B.A.S.-E., M.R.C.-V., and J.F.A.-Z.; supervision, G.A.G.-A., J.L.-M., and J.F.A.-Z.; writing-original draft, M.M.G.-P. and J.F.A.-Z.; writing-review and editing, M.M.G.-P., L.A.O.-R., B.A.S.-E., M.R.C.-V., G.A.G.-A., J.L.-M., R.M., and J.F.A.-Z. All authors have read and agreed to the published version of the manuscript.

Funding: This research received no external funding.

Acknowledgments: M.M.G.-P. acknowledge the national council of science and technology for the fellowship that was received. The technical support of Monica A. Villegas-Ochoa is fully appreciated.

Conflicts of Interest: The authors declare no conflict of interest.

\section{References}

1. USDA. Food Data Central. Available online: https:/fdc.nal.usda.gov/fdc-app.html\#/food-details/168409/ nutrients (accessed on 28 April 2020).

2. Barraza-Álvarez, F.V. Calidad morfológica y fisiológica de pepinos cultivados en diferentes concentraciones nutrimentales. Revista Colombiana de Ciencias Horticolas 2015, 9, 60-71. [CrossRef]

3. Olawuyi, I.F.; Lee, W. Influence of chitosan coating and packaging materials on the quality characteristics of fresh-cut cucumber. Korean J Food Preserv 2019, 26, 371-380. [CrossRef]

4. Reddy, P.P. Bacterial Diseases and Their Management. In In Sustainable Crop Protection under Protected Cultivation; Springer: Berlin/Heidelberg, Germany, 2016; pp. 153-159.

5. Hassan, B.; Chatha, S.A.S.; Hussain, A.I.; Zia, K.M.; Akhtar, N.J.I.J.o.B.M. Recent advances on polysaccharides, lipids and protein based edible films and coatings: A review. Int. J. Biol. Macromol. 2018, 109, 1095-1107. [CrossRef]

6. Yousuf, B.; Qadri, O.S.; Srivastava, A.K. Recent developments in shelf-life extension of fresh-cut fruits and vegetables by application of different edible coatings: A review. LWT 2018, 89, 198-209. [CrossRef]

7. Chiabrando, V.; Giacalone, G.J.E.J.o.F. Agriculture. Effects of edible coatings on quality maintenance of fresh-cut nectarines. Emir. J. Food Agric. 2016, 201-207. [CrossRef]

8. Moreira, M.d.R.; Roura, S.I.; Ponce, A. Effectiveness of chitosan edible coatings to improve microbiological and sensory quality of fresh cut broccoli. LWT Food Sci. Technol. 2011, 44, 2335-2341. [CrossRef]

9. Pavinatto, A.; De Almeida Mattos, A.V.; Malpass, A.C.G.; Okura, M.H.; Balogh, D.T.; Sanfelice, R.C. Coating with chitosan-based edible films for mechanical/biological protection of strawberries. Int. J. Biol. Macromol. 2020, 151, 1004-1011. [CrossRef] [PubMed]

10. Athmaselvi, K.; Sumitha, P.; Revathy, B.J.I.A. Development of Aloe vera based edible coating for tomato. Int. Agrophys. 2013, 27, 369-375. [CrossRef]

11. Poverenov, E.; Zaitsev, Y.; Arnon, H.; Granit, R.; Alkalai-Tuvia, S.; Perzelan, Y.; Weinberg, T.; Fallik, E. Effects of a composite chitosan-gelatin edible coating on postharvest quality and storability of red bell peppers. Postharvest. Biol. Technol. 2014, 96, 106-109. [CrossRef]

12. De Freitas, C.A.S.; de Sousa, P.H.M.; Soares, D.J.; da Silva, J.Y.G.; Benjamin, S.R.; Guedes, M.I.F. Carnauba wax uses in food-A review. Food Chem. 2019, 291, 38-48. [CrossRef]

13. Won, M.Y.; Min, S.C. Coating Satsuma mandarin using grapefruit seed extract-incorporated carnauba wax for its preservation. Food Sci. Biotechnol. 2018, 27, 1649-1658. [CrossRef] [PubMed]

14. Motamedi, E.; Nasiri, J.; Malidarreh, T.R.; Kalantari, S.; Naghavi, M.R.; Safari, M. Performance of carnauba wax-nanoclay emulsion coatings on postharvest quality of 'Valencia' orange fruit. Sci. Hortic 2018, 240, 170-178. [CrossRef] 
15. Rodríguez-Rivera, R.; Herrera-González, J.; Mercado-Silva, E.; Vázquez-Barrios, M.; Rivera-Pastrana, D. Natural coatings and essential oils effects on postharvest quality and antioxidant system of organic avocado (Persea americana Mill 'Hass'). In Proceedings of XXX International Horticultural Congress IHC2018: International Symposium on Strategies and Technologies to Maintain Quality 1275, Istanbul, Turkey, 16 August 2018; pp. 147-154.

16. Dhumal, C.V.; Sarkar, P. Composite edible films and coatings from food-grade biopolymers. J. Food Sci. Technol. 2018, 55, 4369-4383. [CrossRef] [PubMed]

17. Saxena, A.; Sharma, L.; Maity, T. Chapter 34-Enrichment of edible coatings and films with plant extracts or essential oils for the preservation of fruits and vegetables. In Biopolymer-Based Formulations; Pal, K., Banerjee, I., Sarkar, P., Kim, D., Deng, W.-P., Dubey, N.K., Majumder, K., Eds.; Elsevier: Amsterdam, The Netherlands, 2020; pp. 859-880. [CrossRef]

18. Rodriguez-Garcia, I.; Cruz-Valenzuela, M.R.; Silva-Espinoza, B.A.; Gonzalez-Aguilar, G.A.; Moctezuma, E.; Gutierrez-Pacheco, M.M.; Tapia-Rodriguez, M.R.; Ortega-Ramirez, L.A.; Ayala-Zavala, J.F. Oregano (Lippia graveolens) essential oil added within pectin edible coatings prevents fungal decay and increases the antioxidant capacity of treated tomatoes. J. Sci. Food Agric. 2016, 96, 3772-3778. [CrossRef] [PubMed]

19. Wang, K.; Jiang, S.; Pu, T.; Fan, L.; Su, F.; Ye, M. Antifungal activity of phenolic monoterpenes and structure-related compounds against plant pathogenic fungi. Nat. Prod. Res. 2019, 33, 1423-1430. [CrossRef]

20. Kachur, K.; Suntres, Z. The antibacterial properties of phenolic isomers, carvacrol and thymol. Crit. Rev. Food Sci. 2019, 1-12. [CrossRef]

21. Mohammadi, A.; Hashemi, M.; Hosseini, S.M. Chitosan nanoparticles loaded with Cinnamomum zeylanicum essential oil enhance the shelf life of cucumber during cold storage. Postharvest. Biol. Technol. 2015, 110, 203-213. [CrossRef]

22. ORE. ORE-Orégano Orgánico Lippia Graveolens. Available online: http://www.oreganoorganico.com/ (accessed on 15 April 2020).

23. ASTM International. Standard Test Methods for Water Vapor Transmission of Materials; ASTM International: West Conshohocken, PA, USA, 2013.

24. Clinical and Laboratory Standards. Performance Standards for Antimicrobial Susceptibility Testing: Eleventh Informational; Clinical and Laboratory Standards Institute: Wayne, PA, USA, 2001.

25. BAM-FDA. Bacteriological Analytical Manual. Available online: https://www.fda.gov/food/laboratorymethods-food/bacteriological-analytical-manual-bam\#intro (accessed on 10 January 2020).

26. El Knidri, H.; Dahmani, J.; Addaou, A.; Laajeb, A.; Lahsini, A. Rapid and efficient extraction of chitin and chitosan for scale-up production: Effect of process parameters on deacetylation degree and molecular weight. Int. J. Biol. Macromol. 2019, 139, 1092-1102. [CrossRef] [PubMed]

27. Kaya, M.; Ravikumar, P.; Ilk, S.; Mujtaba, M.; Akyuz, L.; Labidi, J.; Salaberria, A.M.; Cakmak, Y.S.; Erkul, S.K. Production and characterization of chitosan based edible films from Berberis crataegina's fruit extract and seed oil. Innov. Food Sci. Emerg. 2018, 45, 287-297. [CrossRef]

28. Verlee, A.; Mincke, S.; Stevens, C.V. Recent developments in antibacterial and antifungal chitosan and its derivatives. Carbohydr. Polym. 2017, 164, 268-283. [CrossRef] [PubMed]

29. Marchese, A.; Arciola, C.R.; Coppo, E.; Barbieri, R.; Barreca, D.; Chebaibi, S.; Sobarzo-Sánchez, E.; Nabavi, S.F.; Nabavi, S.M.; Daglia, M. The natural plant compound carvacrol as an antimicrobial and anti-biofilm agent: Mechanisms, synergies and bio-inspired anti-infective materials. Biofouling 2018, 34, 630-656. [CrossRef]

30. Ochoa, T.A.; Almendárez, B.E.G.; Reyes, A.A.; Pastrana, D.M.R.; López, G.F.G.; Belloso, O.M.; Regalado-González, C. Design and characterization of corn starch edible films including beeswax and natural antimicrobials. Food Bioprocess Technol. 2017, 10, 103-114. [CrossRef]

31. Nair, M.S.; Saxena, A.; Kaur, C. Characterization and antifungal activity of pomegranate peel extract and its use in polysaccharide-based edible coatings to extend the shelf-life of capsicum (Capsicum annuиm L.). Food Bioprocess Technol. 2018, 11, 1317-1327. [CrossRef]

32. Santos, F.K.G.d.; Silva, K.N.d.O.; Xavier, T.D.N.; Leite, R.H.d.L.; Aroucha, E.M.M. Effect of the addition of carnauba wax on physicochemical properties of chitosan films. Mater. Res. 2017, 20, 479-484. [CrossRef]

33. Haq, M.A.; Hasnain, A.; Jafri, F.A.; Akbar, M.F.; Khan, A. Characterization of edible gum cordia film: Effects of beeswax. LWT Food Sci. Technol. 2016, 68, 674-680. [CrossRef] 
34. Zhang, R.; Wang, W.; Zhang, H.; Dai, Y.; Dong, H.; Kong, L.; Hou, H.J.C.P. Effects of preparation conditions on the properties of agar/maltodextrin-beeswax pseudo-bilayer films. Carbohydr. Polym. 2020, 236, 116029. [CrossRef]

35. Elsabee, M.Z.; Morsi, R.E.; Fathy, M. Chapter 44 - Chitosan-Oregano Essential Oil Blends Use as Antimicrobial Packaging Material. In Antimicrobial Food Packaging; Barros-Velázquez, J., Ed.; Academic Press: San Diego, CA, USA, 2016; pp. 539-551. [CrossRef]

36. Fernández-Pan, I.; Maté, J.I.; Gardrat, C.; Coma, V. Effect of chitosan molecular weight on the antimicrobial activity and release rate of carvacrol-enriched films. Food Hydrocoll. 2015, 51, 60-68. [CrossRef]

37. Yuan, G.; Lv, H.; Yang, B.; Chen, X.; Sun, H. Physical properties, antioxidant and antimicrobial activity of chitosan films containing carvacrol and pomegranate peel extract. Molecules 2015, 20, 11034-11045. [CrossRef]

38. Ruiz-Navajas, Y.; Viuda-Martos, M.; Sendra, E.; Perez-Alvarez, J.; Fernández-López, J. In vitro antibacterial and antioxidant properties of chitosan edible films incorporated with Thymus moroderi or Thymus piperella essential oils. Food Control 2013, 30, 386-392. [CrossRef]

39. Bosquez-Molina, E.; Guerrero-Legarreta, I.; Vernon-Carter, E. Moisture barrier properties and morphology of mesquite gum-candelilla wax based edible emulsion coatings. Food Res. Int. 2003, 36, 885-893. [CrossRef]

40. Endlein, E.; Peleikis, K.H. Natural Waxes-Properties, Compositions and Applications. SÖFW-Journal 2011, 137.

41. Doan, C.D.; Tavernier, I.; Okuro, P.K.; Dewettinck, K. Internal and external factors affecting the crystallization, gelation and applicability of wax-based oleogels in food industry. Innov. Sci. Emerg. Technol. 2018, 45, 42-52. [CrossRef]

42. Miranda, M.; Gozalbo, A.M.; Sun, X.; Plotto, A.; Bai, J.; de Assis, O.; Ferreira, M.; Baldwin, E. Effect of mono and bilayers of carnauba wax based nano-emulsion and HPMC coatings on popst-harvest quality of'redtainung'papaya. Proceedings of Embrapa Instrumentação-Artigo em Anais de Congresso (ALICE), São Paulo, Brazil, 3-5 December 2019.

43. Chiabrando, V.; Giacalone, G. Effect of chitosan and sodium alginate edible coatings on the postharvest quality of fresh-cut nectarines during storage. Int. J. Trop. Subtrop. Hortic. 2016, 71, 79-85. [CrossRef]

44. Tokatl1, K.; Demirdöven, A. Effects of chitosan edible film coatings on the physicochemical and microbiological qualities of sweet cherry (Prunus avium L.). Scientia Hortic 2020, 259, 108656. [CrossRef]

45. Alvarez, M.V.; Ponce, A.G.; Moreira, M.d.R. Antimicrobial efficiency of chitosan coating enriched with bioactive compounds to improve the safety of fresh cut broccoli. LWT Food Sci. Technol. 2013, 50, 78-87. [CrossRef]

46. Walker, G.M.; White, N.A. Introduction to fungal physiology. In Fungi: Biology and Applications; John Wiley \& Sons, Inc.: Hoboken, NJ, USA, 2017; pp. 1-35. [CrossRef]

47. Velickova, E.; Winkelhausen, E.; Kuzmanova, S.; Alves, V.D.; Moldão-Martins, M. Impact of chitosan-beeswax edible coatings on the quality of fresh strawberries (Fragaria ananassa cv Camarosa) under commercial storage conditions. LWT Food Sci. Technol. 2013, 52, 80-92. [CrossRef]

48. Kanetis, L.; Exarchou, V.; Charalambous, Z.; Goulas, V. Edible coating composed of chitosan and Salvia fruticosa Mill. extract for the control of grey mould of table grapes. J. Sci. Food Agric. 2017, 97, 452-460. [CrossRef]

49. Kumar, V.; Sangeetha, K.; Ajitha, P.; Aisverya, S.; Sashikala, S.; Sudha, P.J.H.o.B.A.; Applications, M. Chitin and Chitosan: The Defense Booster in Agricultural Field. In In Handbook of Biopolymers: Advances and Multifaceted Application; Vijayalakshmi, K.S.K., Ajitha, P., Aisverya, S., Sashikala, S., Sudha, P.N., Eds.; Jenny Stanford Publishing: New York, NY, USA, 2018; p. 93.

(C) 2020 by the authors. Licensee MDPI, Basel, Switzerland. This article is an open access article distributed under the terms and conditions of the Creative Commons Attribution (CC BY) license (http://creativecommons.org/licenses/by/4.0/). 